\title{
Further investigation of risk elements content in the bones of wild rodents from a polluted area in Slovakia
}

\author{
Monika Martiniakova ${ }^{1 \dagger}$, Radoslav Omelka ${ }^{2 \dagger}$, Birgit Grosskopf ${ }^{3 *}$, Hana Duranova ${ }^{1}$, Robert Stawarz ${ }^{4 \dagger}$ \\ and Ivan Balaz ${ }^{5}$
}

\begin{abstract}
Background: Wild rodents are suitable for monitoring environmental pollution and exposure risk assessment for people living in contaminated areas. The content of selected risk elements in the femora of bank vole (Myodes glareolus), yellow-necked mouse (Apodemus flavicollis) and wood mouse (Apodemus sylvaticus) was estimated from the Kolíňany area of Slovakia, which is characterized by a high degree of environmental pollution. The rodents were trapped in February 2011 using standard theriological methods. All animals $(n=32)$ were adult males in good physical condition. The concentrations of $\mathrm{Fe}, \mathrm{Cu}, \mathrm{Zn}$ and $\mathrm{Ni}$ in their bones were determined by atomic absorption spectrophotometry.

Results: The highest concentrations of Fe and Cu were detected in the bones of yellow-necked mouse. Significant differences were observed for the content of Fe between A. flavicollis and M. glareolus $(P<0.05)$. The highest levels of $\mathrm{Zn}$ and Ni were found in the femora of wood mouse; however, significant differences were not detected between the rodents. Moreover, the concentrations of $\mathrm{Cu}, \mathrm{Zn}$ and Ni were significantly higher in the bones of all three species $(P<0.05)$ in comparison with the values obtained in the same animal species at the same site in February 2007.
\end{abstract}

Conclusions: Our results demonstrate an increased accumulation of $\mathrm{Cu}, \mathrm{Zn}$ and $\mathrm{Ni}$ in the femora of M. glareolus, $\mathrm{A}$. flavicollis and A. sylvaticus from the Kolínany area and thus indicate towards ongoing contamination of this locality.

Keywords: Risk elements, Bone, Wild rodents, Slovakia

\section{Background}

The importance of monitoring and studying the effect of various risk elements on living organisms has become critical in the last few decades; specifically in East and Central Europe. There are a number of ecological studies that have demonstrated that rodents are essential canary-type species useful in monitoring pollutant issues for their habitats. Rodents are the sentinels of man-made environmental pollution crises.

Various studies of wild rodents have revealed that they are able to accumulate a wide spectrum of pollutants

*Correspondence: birgit.grosskopf@biologie.uni-goettingen.de

${ }^{\dagger}$ Monika Martiniakova, Radoslav Omelka and Robert Stawarz contributed equally to this work

${ }^{3}$ Institute of Zoology and Anthropology, Georg-August University, 37

073 Göttingen, Germany

Full list of author information is available at the end of the article which are present in the ecosystem $[1,2]$. In addition, the pattern of risk elements distribution and their levels in various tissues of the rodents are similar to those found in humans $[3,4]$. This makes rodents ideal for monitoring environmental pollution, as well as for evaluating the exposure risk for people living in a contaminated area $[4$, 5].

The bank vole (Myodes glareolus, formerly Clethrionomys glareolus, Schreber, 1780) is a small microtine rodent that is common throughout Europe and it is one of the most common woodland rodents in Slovakia. Seeds, fruits and green vegetation constitute about $44 \%$ of their food, insects, earthworms and other invertebrates between 9 and $23 \%$, depending on the season, and in winter they add tree bark to their food [6,7]. This species has been used to monitor environmental pollution from 
a variety of technogenic sources up to date $[8,9]$. Mice from the genus Apodemus have been shown to be relevant pollution bioindicators [10-13]. The yellow-necked mouse (Apodemus flavicollis) and wood mouse (Apodemus sylvaticus) belong to the most dominant rodent species in Slovakia. The yellow-necked mouse is slightly larger and more brightly colored than the wood mouse. It eats mainly seeds, especially acorns, beech mast and hazel nuts, but it also consumes insects and other invertebrate as food [14]. The diet of the wood mouse consists of roots, grains, seeds, berries, nuts, grasses, grain kernels, fruits and insects [15].

Since bone can serve as a good biomarker of long-term accumulation of various risk elements including nonessential and essential metals, we analysed concentrations of selected essential metals $(\mathrm{Fe}, \mathrm{Cu}, \mathrm{Zn}$, and $\mathrm{Ni}$ ) in the femora of the three rodent species mentioned above. These metals are necessary for proper functioning of living organisms. The uptake and distribution of these biologically essential metals is physiologically regulated, in contrast to other non-essential elements [16]. However, essential metals can also produce toxic effects when their intake reaches high concentrations [17].

In our study, all wild rodents were trapped from the Kolínany area of Slovakia which is considered as a heavily polluted region. Our earlier experiments focused on the determination of various risk elements in the bones of M. glareolus, A. flavicollis and A. sylvaticus in February 2007 and the results demonstrated significantly higher concentrations of $\mathrm{Fe}, \mathrm{Cu}$ and $\mathrm{Zn}$ in the bones of bank voles from the Kolínany area as compared to those from the Nováky area of Slovakia [18]. The Nováky region of Slovakia is generally considered to be strongly polluted region in Slovakia because of a localization of many sources of environmental contamination, e.g. Nováky chemical plant, Coal power station in Nováky, Handlová-Cígel mines.

Furthermore, a significantly higher content of $\mathrm{Ni}$ and $\mathrm{Zn}$ was found in the femora of yellow-necked mice and wood mice from the Kolínany locality in comparison with the Nováky area [19]. Therefore, in addition to the determination of risk elements in the bones of wild rodents, we compared the present results with those obtained in the year $2007[18,19]$.

\section{Methods}

The individuals of bank vole (M. glareolus, $\mathrm{n}=14)$, yellow-necked mouse (A. flavicollis, $\mathrm{n}=6$ ) and wood mouse (A. sylvaticus, $\mathrm{n}=12$ ) were obtained by means of the standard theriological methods and procedures from wood ecosystems [20] in February 2011. The wild rodents were trapped near the water pond in Kolíňany (Nitra district, Slovakia; Fig. 1) which is located $\sim 10 \mathrm{~km}$ away from the town Nitra and it is considered to be a heavily polluted region $[18,19]$. Possible sources of pollution for this district are small factories, the application of agricultural chemicals, traffic pollution and the waste from large local industrial complexes. All animals caught were

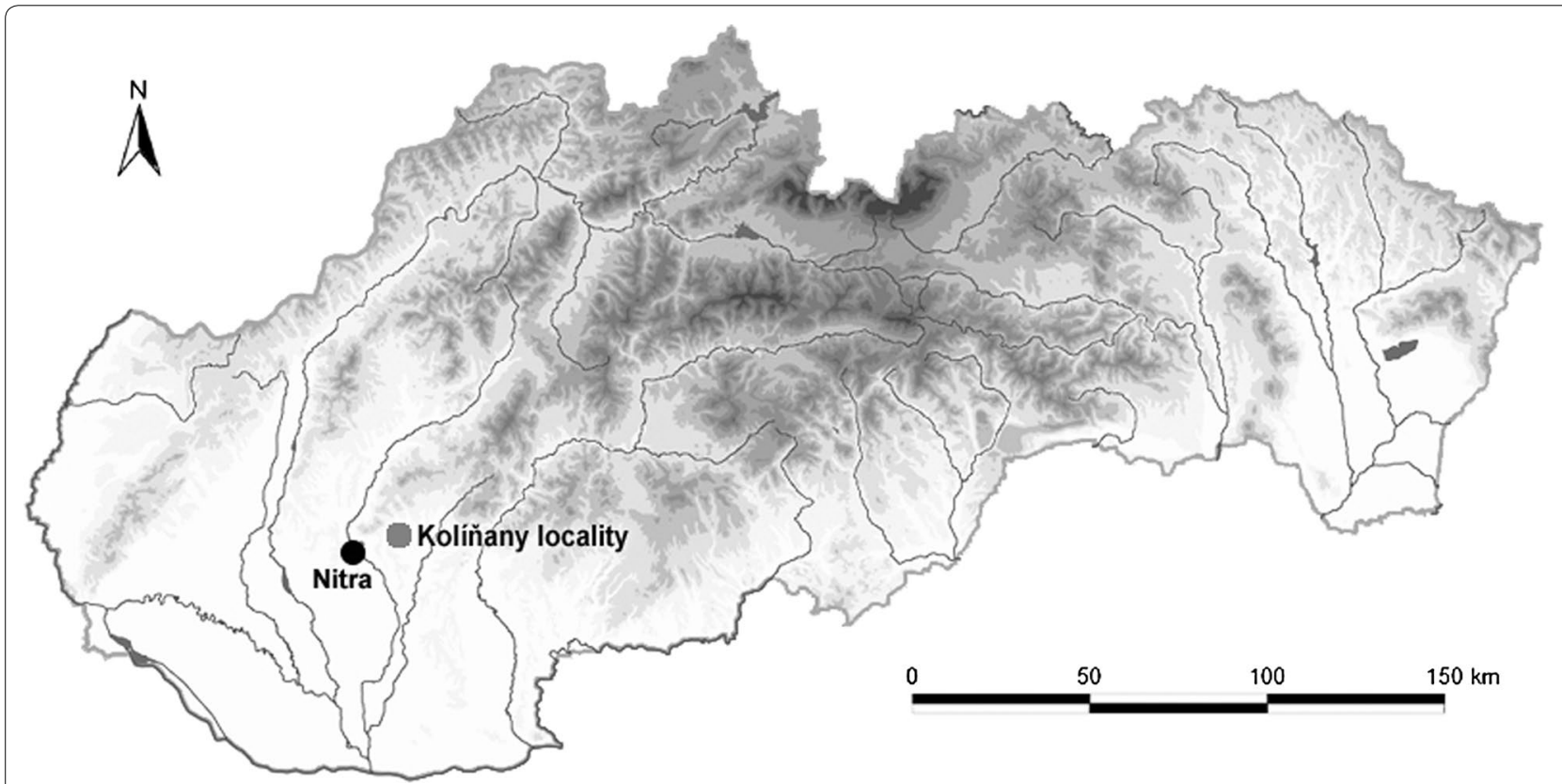

Fig. 1 Map of investigated locality. The figure shows a location of investigated Kolíñany locality (GPS coordinates: N48 $21^{\prime} 18.28^{\prime \prime}$, E1 $8^{\circ} 12^{\prime} 36.03^{\prime \prime}$ ) which is situated near the Nitra city 
adult males (aged 4-5 months of age as determined by dental wear). They appeared to be in good physical condition and without gross lesions at necropsy. All procedures were approved by the Ministry of Environment of the Slovak Republic.

The concentrations of selected risk elements $(\mathrm{Fe}, \mathrm{Cu}$, $\mathrm{Zn}$, and $\mathrm{Ni}$ ) were estimated in both the femora of all the investigated rodents $(n=64)$ using the method of atomic absorption spectrophotometry (Perkin Elmer $4100 \mathrm{ZL}$ ) in a graphite furnace [21]. The tissue samples were kept at $-18{ }^{\circ} \mathrm{C}$ until analysis. In the laboratory, the samples were dried at $105{ }^{\circ} \mathrm{C}$ until dry mass was obtained. Then, the bones were weighed (minimum $2 \mathrm{~g}$ ) and digested in concentrated nitric acid at $90{ }^{\circ} \mathrm{C}$ for $5 \mathrm{~h}$. Prior to analysis, the samples were diluted to $10 \mathrm{ml}$ with distilled water. All metal concentrations were expressed on a dry weight basis in $\mathrm{mg} \mathrm{kg}^{-1}$.

From the final data, basic statistical characteristics were calculated (mean, standard deviation, minimum, maximum, median). The analysis of variance and Scheffe test were used for comparison of risk elements content between species. The $T$ test was applied to compare the present data with those obtained in February 2007 [18, 19].

\section{Results and discussion}

The concentrations of selected risk elements $(\mathrm{Fe}, \mathrm{Cu}, \mathrm{Zn}$, and $\mathrm{Ni}$ ) in the femora of M. glareolus, A. flavicollis and A. sylvaticus from the Kolínany area are listed in Table 1. The highest concentrations of $\mathrm{Fe}$ and $\mathrm{Cu}$ were detected in the bones of yellow-necked mice. Significant differences were observed for the content of Fe between A. flavicollis and M. glareolus $(P<0.05)$. The highest levels of $\mathrm{Zn}$ and $\mathrm{Ni}$ were found in the femora of wood mice; however, significant differences were not detected between the rodents.

We observed a higher concentration of $\mathrm{Zn}$ in the femora of M. glareolus in comparison with the data reported by Milton et al. [8]. These investigators analysed $\mathrm{Zn}$ concentration $\left(173 \pm 5.1 \mu \mathrm{g} \mathrm{g}^{-1}\right.$ dry weight $)$ in the femora of bank voles trapped at the contaminated, unused $\mathrm{Pb}$ mine at Frongoch in west Wales. In contrast, $\mathrm{Zn}$ concentration in the bones of bank voles from the Kolínany area was lower than the value $\left(261.1 \pm 7.4 \mu \mathrm{g} \mathrm{g}^{-1}\right.$ dry weight) reported by Milton and Johnson [22], who analysed femora of laboratory-bred bank voles exposed to increased levels of dietary Zn.

Also, higher concentrations of $\mathrm{Zn}$ and Fe were detected in the femora of A. flavicollis in our study as compared to those observed by Damek-Poprawa and Sawicka-Kapusta [4]. These authors determined the content of $\mathrm{Zn}$ and $\mathrm{Fe}$ in the femur of yellow-necked mice from $\mathrm{Zn}$ smelters in Bukowno (Poland) which are considered to be extremely
Table 1 Concentrations of risk elements in the femora of wild rodents from the Kolíňany area

\begin{tabular}{|c|c|c|c|c|}
\hline Species & $\begin{array}{l}\mathrm{Fe} \\
\left(\mathrm{mg} \mathrm{kg}^{-1}\right)\end{array}$ & $\left.\begin{array}{l}\mathrm{Cu} \\
(\mathrm{mg} \mathrm{kg} \\
-1\end{array}\right)$ & $\begin{array}{l}\mathrm{Zn} \\
(\mathrm{mg} \mathrm{kg} \\
-1)\end{array}$ & $\begin{array}{l}\mathrm{Ni} \\
\left(\mathrm{mg} \mathrm{kg}^{-1}\right)\end{array}$ \\
\hline \multicolumn{5}{|c|}{ Myodes glareolus (1) } \\
\hline$x$ & 197.26 & 62.63 & 241.73 & 26.94 \\
\hline sd & 67.36 & 19.45 & 19.28 & 5.59 \\
\hline $\min$ & 123.24 & 42.08 & 217.74 & 19.26 \\
\hline $\max$ & 286.58 & 88.79 & 268.94 & 32.06 \\
\hline med & 197.92 & 61.8 & 245.03 & 29.21 \\
\hline \multicolumn{5}{|c|}{ Apodemus flavicollis (2) } \\
\hline$x$ & 240.28 & 69.94 & 239.94 & 29.58 \\
\hline sd & 75.14 & 20.03 & 52.61 & 9.87 \\
\hline $\min$ & 154.46 & 61.75 & 187.39 & 13.71 \\
\hline $\max$ & 330.89 & 109.23 & 316.46 & 45.83 \\
\hline med & 277.91 & 85.62 & 272.34 & 26.98 \\
\hline \multicolumn{5}{|c|}{ Apodemus sylvaticus (3) } \\
\hline$x$ & 215.46 & 68.78 & 244.74 & 30.79 \\
\hline $\mathrm{sd}$ & 44.78 & 13.58 & 46.58 & 10.21 \\
\hline $\min$ & 171.68 & 52.82 & 196.79 & 9.32 \\
\hline $\max$ & 277.32 & 85.34 & 294.54 & 58.09 \\
\hline med & 206.41 & 68.49 & 243.81 & 27.87 \\
\hline Scheffe test & $1: 2(+)$ & NS & NS & NS \\
\hline
\end{tabular}

$x$ Mean, sd standard deviation, min minimum, max maximum, med median, $+P<0.05$, NS non-significant changes

polluted (Zn concentration $166.3 \pm 7.6 \mu \mathrm{g} \mathrm{g} \mathrm{g}^{-1} \mathrm{dry}$ weight, Fe concentration $153.0 \pm 9.9 \mu \mathrm{g} \mathrm{g}^{-1}$ dry weight).

It is interesting to note that the concentrations of $\mathrm{Cu}$, $\mathrm{Zn}$ and $\mathrm{Ni}$ were significantly higher in the bones of all three wild rodents in our study in comparison with the values obtained in the same animal species at the same site (Kolínany) in February 2007 (Table 2). Therefore, our results demonstrate the increased accumulation of these elements in the femora of the rodents investigated and thus indicate towards the ongoing contamination of this locality. This fact can be explained by intensive agricultural production and subsequent contamination of the soil, water, and food, by traffic pollution, as well as by various factories and industrial zones in western Slovakia. These factors are present today and they were also problematic in the recent past (e.g. production of $\mathrm{Ni}$ in Sered' and its dumping sites) [23].

In general, the intensive agricultural production and the use of agrochemicals are characteristic for the whole region of Nitra. It is known that the application of agrochemicals can lead to a higher accumulation of specific elements, including $\mathrm{Ni}, \mathrm{Cu}$ and $\mathrm{Zn}$ into the soil [24, 25]. In addition, there is heavy road traffic near the capture locality, which is also considered to be a significant source of risk elements that has a potential to be transported by air flow over large distances. According to 
Table 2 Comparison of risk elements content with data obtained by Martiniaková et al. [18, 19]

\begin{tabular}{|c|c|c|c|c|}
\hline $\begin{array}{l}\text { Species/ } \\
\text { study }\end{array}$ & $\begin{array}{l}\mathrm{Fe} \\
\left(\mathrm{mg} \mathrm{kg}^{-1}\right)\end{array}$ & $\begin{array}{l}\mathrm{Cu} \\
\left(\mathrm{mg} \mathrm{kg}^{-1}\right)\end{array}$ & $\begin{array}{l}\mathrm{Zn} \\
\left(\mathrm{mg} \mathrm{kg}^{-1}\right)\end{array}$ & $\begin{array}{l}\mathrm{Ni} \\
\left(\mathrm{mg} \mathrm{kg}^{-1}\right)\end{array}$ \\
\hline \multicolumn{5}{|c|}{ Myodes glareolus — present study } \\
\hline$x$ & 197.26 & 62.63 & 241.73 & 26.94 \\
\hline sd & 67.36 & 19.45 & 19.28 & 5.59 \\
\hline \multicolumn{5}{|c|}{ Myodes glareolus —-study of Martiniaková et al. [18] } \\
\hline$x$ & 212.99 & 4.16 & 188.55 & 9.52 \\
\hline sd & 52.27 & 2.1 & 21.61 & 2.8 \\
\hline T-test & NS & + & + & + \\
\hline \multicolumn{5}{|c|}{ Apodemus flavicollis — present study } \\
\hline$x$ & 240.28 & 69.94 & 239.94 & 29.58 \\
\hline sd & 75.14 & 20.03 & 52.61 & 9.87 \\
\hline \multicolumn{5}{|c|}{ Apodemus flavicollis — study of Martiniaková et al. [19] } \\
\hline$x$ & 163.27 & 4.43 & 143.84 & 9.16 \\
\hline sd & 73.91 & 1.19 & 16.52 & 1.89 \\
\hline T-test & + & + & + & + \\
\hline \multicolumn{5}{|c|}{ Apodemus sylvaticus - present study } \\
\hline$x$ & 215.46 & 68.79 & 244.74 & 30.79 \\
\hline sd & 44.78 & 13.58 & 46.58 & 20.21 \\
\hline \multicolumn{5}{|c|}{ Apodemus sylvaticus — study of Martiniaková et al. [19] } \\
\hline$x$ & 109.1 & 3.33 & 147.55 & 7.8 \\
\hline sd & 35.61 & 1.06 & 13.35 & 0.84 \\
\hline T-test & + & + & + & + \\
\hline
\end{tabular}

$x$ mean, $s d$ standard deviation, $+P<0.05, N S$ non-significant changes

Blagojevic et al. [16], at least $90 \%$ of the metals in road runoff consist of $\mathrm{Cu}, \mathrm{Zn}$ and $\mathrm{Pb}$. There is also a possibility of falling dust being transported in the air from large industrial regions, such as Bratislava, Vienna, Budapest, or factories near the Nitra district. This hypothesis may be supported by a study indicating the possibility of the long range transportation of various xenobiotics [26].

Since mechanisms of heavy metals bioaccumulation are very similar in mammals whatever area they occupy [16], our results could also be extrapolated on humans living in the Kolíňany area.

\section{Conclusions}

The accumulation of selected risk elements $(\mathrm{Fe}, \mathrm{Cu}, \mathrm{Zn}$, and $\mathrm{Ni}$ ) in the femora of bank vole, yellow-necked mouse and wood mouse from the Koliňany area was investigated in the present study. The highest concentrations of Fe and $\mathrm{Cu}$ were detected in the bones of yellow-necked mouse. Significant differences were observed for the concentration of Fe between yellow-necked mouse and bank vole $(P<0.05)$. The highest levels of $\mathrm{Zn}$ and $\mathrm{Ni}$ were found in the femora of wood mouse; however, significant differences were not detected between the rodents. The concentrations of $\mathrm{Cu}, \mathrm{Zn}$ and $\mathrm{Ni}$ were significantly higher in the bones of all three species in our study in comparison with the values obtained in the same animal species at the same site in the year 2007. This study finds a need for a continuation of the monitoring of heavy metal levels in Central Europe environments, specifically in the Nitra district.

\section{Authors' contributions}

MM was responsible for coordinating the study and writing the article. RO was responsible for statistical analyses. BG helped to draft the article. HD was responsible for sample preparation for atomic absorption spectrophotometry. RS was responsible for determination of risk elements content. IB was responsible for animal trapping. All authors have read and approved the final manuscript.

\section{Author details}

${ }^{1}$ Department of Zoology and Anthropology, Constantine the Philosopher University, 94974 Nitra, Slovakia. ${ }^{2}$ Department of Botany and Genetics, Constantine the Philosopher University, 94974 Nitra, Slovakia. ${ }^{3}$ Institute of Zoology and Anthropology, Georg-August University, 37073 Göttingen, Germany. ${ }^{4}$ Institute of Biology, Krakow Pedagogical University, 31054 Kraków, Poland. ${ }^{5}$ Department of Ecology and Environmentalistics, Constantine the Philosopher University, 94901 Nitra, Slovakia.

\section{Acknowledgements}

This study was supported by the Grant KEGA 035UKF-4/2013. This article was written during realization of the project LAGEZ No. 26220120070 supported by the Operational Programme Research and Development funded from the European Regional Development Fund. The authors gratefully acknowledge the revision of the English text by Dr. Shubhadeep Roychoudhury (Assam University, Silchar, India).

\section{Compliance with ethical guidelines}

\section{Competing interests}

The authors declare that they have no competing interests.

Received: 26 May 2015 Accepted: 14 August 2015

Published online: 25 August 2015

\section{References}

1. leradi LA, Moreno S, Bolívar JP, Cappai A, Di Benedetto A, Cristaldi M (1998) Free-living rodents as bioindicators of genetic risk in natural protected areas. Environ Pollut 102:265-268

2. Wijnhoven S, Leuven RSEW, van der Velde G, Jungheim G, Koelemij El, de Vries FT et al (2007) Heavy-metal concentrations in small mammals from a diffusely polluted floodplain: importance of species- and locationspecific characteristics. Arch Environ Contam Toxicol 52:603-613

3. Shore RF, Rattner BA (2001) Ecotoxicology of wild mammals. Wiley, London

4. Damek-Poprawa M, Sawicka-Kapusta K (2003) Damage to the liver, kidney, and testis with reference to burden of heavy metals in yellownecked mice from areas around steelworks and zinc smelters in Poland. Toxicology 186:1-10

5. O'Brien DJ, Kaneene JB, Poppenga RH (1993) The use of mammals as sentinels for human exposure to toxic contaminants in the environment. Environ Health Perspect 99:351-368

6. Zemanek M (1972) Food and feeding habits of rodents in a deciduous forest. Acta Theriol 23:315-325

7. Gdula-Argasinska J, Appleton J, Sawicka-Kapusta K, Spence B (2004) Further investigation of the heavy metal content of the teeth of the bank vole as an exposure indicator of environmental pollution in Poland. Environ Pollut 131:71-79

8. Milton A, Cooke JA, Johnson MS (2003) Accumulation of lead, zinc, and cadmium in a wild population of Clethrionomys glareolus from an abandoned lead mine. Arch Environ Contam Toxicol 44:405-411

9. Topolska K, Sawicka-Kapusta K, Cieslik E (2004) The effect of contamination of the Krakow region on heavy metals content in the organs of bank voles (Clethrionomys glareolus, Schreber, 1780). Pol J Environ Stud 13:103-109 
10. Metcheva R, Teodorova S, Topashka-Ancheva M (2001) A comparative analysis of the heavy metals and toxic elements loading indicated by small mammals in different Bulgarian regions. Acta Zool Bulg 53:61-80

11. Milton A, Johnson MS, Cooke JA (2002) Lead within ecosystems on metalliferous mine tailings in Wales and Ireland. Sci Total Environ 299:177-190

12. Milton A, Cooke JA, Johnson MS (2004) A comparison of cadmium in ecosystems on metalliferous mine tailings in Wales and Ireland. Water Air Soil Pollut 153:157-172

13. leradi LA, Zima J, Allegra F, Kotlánová E, Campanella L, Grossi R et al (2003) Evaluation of genotoxic damage in wild rodents from a polluted area in the Czech Republic. Folia Zool 52:57-66

14. Jančová A, Massányi P, Gálová J (2002) The concentration of cadmium and lead in liver and kidneys in Apodemus flavicollis and Clethrionomys glareolus. Folia Vet 46:65-67

15. Nowak RM (1991) Walker's mammals of the world, vol II. Johns Hopkins University Press, Baltimore

16. Blagojevic J, Jovanovic V, Stamenkovic G, Jojic V, Bugarski-Stanojevic V, Adnadevic T et al (2012) Age differences in bioaccumulation of heavy metals in populations of the black-striped field mouse, Apodemus agrarius (Rodentia, Mammalia). Int J Environ Res 6:1045-1052

17. Angelova V, Ivanova R, Delibaltova V, Ivanov K (2004) Bioaccumulation and distribution of heavy metals in fiber crops (flax, cotton, and hemp). Ind Crops Prod 19:197-205

18. Martiniaková M, Omelka R, Jančová A, Stawarz R, Formicki G (2011) Concentrations of selected heavy metals in bones and femoral bone structure of bank (Myodes glareolus) and common (Microtus arvalis) voles from different polluted biotopes in Slovakia. Arch Environ Contam Toxicol 60:524-532
19. Martiniaková M, Omelka R, Jančová A, Stawarz R, Formicki G (2010) Heavy metal content in the femora of yellow-necked mouse (Apodemus flavicollis) and wood mouse (Apodemus sylvaticus) from different types of polluted environment in Slovakia. Environ Monit Assess 171:651-660

20. Jančová A, Massányi P, Nad'P, Koréneková B, Skalická M, Drábeková J et al (2006) Accumulation of heavy metals in selected organs of yellow necked mouse (Apodemus flavicollis). Ekol Bratisl 25:19-26

21. Stawarz R, Zakrzewski M, Marenčík A, Hraška Š (2003) Heavy metal concentration in the toad Bufo Bufo from a region of Mochovce, Slovakia. Ekol Bratisl 22:292-297

22. Milton A, Johnson MS (1999) Biomonitoring of contaminated mine tailings through age accumulation of trace metals in the bank vole (Clethrionomys glareolus). J Environ Monit 1:219-225

23. Gasparik J, Dobias M, Capcarova M, Smehyl P, Slamecka J, Bujko J et al (2012) Concentration of cadmium, mercury, zinc, copper and cobalt in the tissues of wild boar (Sus scrofa) hunted in the western Slovakia. Environ Sci Health A Tox Hazard Subst Environ Eng 47:1212-1216

24. Basta NT, Ryan JA, Chaney RL (2005) Trace element chemistry in residualtreated soil: key concepts and metal bioavailability. J Environ Qual 34:49-63

25. Wuana RA, Okieimen FE (2011) Heavy metals in contaminated soils: a review of sources, chemistry, risks and best available strategies for remediation. ISRN Ecol Article ID 402647:20

26. Coggins AM, Jennings SG, Ebinghaus R (2006) Accumulation rates of the heavy metals lead, mercury and cadmium in ombrotrophic peatlands in the west of Ireland. Atmos Environ 40:260-278

\section{Submit your next manuscript to BioMed Central and take full advantage of:}

- Convenient online submission

- Thorough peer review

- No space constraints or color figure charges

- Immediate publication on acceptance

- Inclusion in PubMed, CAS, Scopus and Google Scholar

- Research which is freely available for redistribution

Submit your manuscript at

www.biomedcentral.com/submit

C BioMed Central 